\title{
Who holds power in land-use decisions? Implications for REDD+ in Indonesia
}

\author{
Rodd Myers ${ }^{1}$ and Fitrian Ardiansyah²
}

\section{Key messages}

- In different provinces or districts, the same laws can be applied in very different ways.

- Participation of customary land users and local communities remains ad hoc and requires that implementing regulations are strengthened, as the existing safeguarding laws are not sufficiently specific.

- Further developments of safeguarding laws and regulations (specifically the distribution of benefits from carbon financing) need to be well defined and better aligned with decentralization processes.

- Subnational actors are unclear on their role in a national REDD+ strategy and how they will be involved in decision making.

- REDD+ is challenged by a misalignment between land use decision-making powers and REDD+ management powers allocated to different bodies and levels.

\section{Introduction}

Amid the sense of urgency to operationalize REDD+ in Indonesia, a number of unanswered questions remain: who has jurisdiction for REDD+? Which ministries and departments will play what roles? How are local communities involved in decision making? What role will provinces and districts play? And how will incentives be targeted to change land-use behavior? CIFOR's research on multilevel governance under the Global Comparative Study on REDD+ aims to elucidate some of these issues by highlighting how different actors influence land-use decision making, and specifically what that might mean for REDD+.

The research is based on two CIFOR studies: a legal study in land-use decision making and a land-use change study based on 149 interviews in Central and West Kalimantan. Ten cases of land-use change were selected through key informant interviews: some aimed at decreasing carbon emissions, while others involved the conversion

CIFOR

2 Pelangi Indonesia of forests to other uses, which would increase carbon emissions. Specific cases included REDD+ demonstration and conservation projects, oil palm developments, village and community forests, and a national park. In-depth interviews were conducted with a chain of government, private sector, community, customary user and nongovernmental actors at subnational and national levels.

This InfoBrief focuses on decision making from a multilevel governance perspective, which includes looking at the decisions of actors from a range of sectors and levels, and on the role these stakeholders have played in landuse change. Decision making is understood within the context of decentralization, a process that Indonesia has been undergoing since 1998. The first section explores decentralization and land-use decision making; the second section analyzes the role of each type of actor in land-use change; and the final section presents implications for REDD+.

\section{Decentralization}

The processes and results of decentralization play important roles in influencing land-use changes in Indonesia. The degree of decentralization of land-use decision making depends primarily on whether land is designated as forest or 
non-forest (Area Penggunaan Lain - APL) and the type of land-use change by sector. Although non-forest land-use decision making has been largely decentralized to the districts, authority over forests (especially production and conservation forests) remains highly centralized under the Ministry of Forestry. In recent years, there have been some examples of increased provincial and district participation in decision making around forest management. ${ }^{3}$ In Central and West Kalimantan, the national government is involved in the verification required for approving operating permits of village and community forests (hutan desa and hutan kemasyarakatan, respectively ${ }^{4}$ ) through the Watershed Management and Social Forestry Authority (BPDASPS), but the final authorization of forest management permits (IUP) rests with district officials. In some specific jurisdictions, partial management authority over forests has been decentralized, such as in Kapuas Hulu, Berau and Malinau districts. These transfers of powers are detailed in Ministry of Forestry regulation 47 of 2011 and are part of REDD+ demonstration activities. In other cases, district governments have issued regulations to establish indigenous and protected forests; they serve as management reserves, but do not necessarily confer landtenure security for customary users outside the national forest estate (kawasan hutan).

Overall, the state, through the Ministry of Forestry, retains control over the Indonesian forest estate; nevertheless, this assumption has been successfully challenged in the Constitutional Court: the Ministry of Forestry cannot establish boundaries of the national forest estate without due process. ${ }^{5}$ The court's follow-up decision ${ }^{6}$ opened the door for customary claims in forest land that could result in the transfer of forestland control from the Ministry of Forestry to customary users. The effects of these court decisions are not yet clear, and the regulations are yet to be drafted.

3 In Indonesia, the first administrative subdivision is the province, followed by districts (or regencies), subdistricts and villages.

4 The primary differences between village forest and community forest are that (a) a village forest is managed completely communally whereas a community forest can recognize customary land tenure (usually by household); (b) community forests in West Kalimantan require district head (bupati) approval whereas village forests require the approval of the governor or Ministry of Forestry, depending on the province; and (c) a village forest is managed through the authority of the head of village, while a community forest is managed by a farmer association or co-operative.

5 See MK45/PUU-IX/2011 on the process of designating forestland and MK34/PUU-IX/2011 on the inclusion of customary users in forestland designation.

6 MK35/PUU-X/2012
At the same time, as we show in our report, financial transfer and revenue-sharing mechanisms motivate exploitation of natural resources.? Indonesia's intergovernmental fiscal transfer system (from the central to local governments) does not yet have any clear arrangements to incentivize ${ }^{8}$ better natural resource management, including mechanisms to address deforestation. Rather, provincial and district governments seek to increase direct income by exploiting natural resources, as will be seen below.

\section{Actors in land-use change}

\section{Governments}

Government (mostly at national and district levels) has the strongest authority over land-use change overall, as demonstrated in our research. As already mentioned, even under decentralization forests remain under the purview of the Ministry of Forestry. At the provincial level, decisions on forests include the regional offices of the central government's BPDASPS, thereby ensuring the Ministry of Forestry's reach into provincial-level decisions. The National Land Agency (BPN) has a presence at district levels and plays a role in facilitating land-use changes outside of the forest estate through the permitting processes.

Although provincial governments received greater powers under Law 32/2004 and 33/2004, they, along with subdistrict governments, have the least amount of influence over land-use change. District heads have important authority over issuing permits for most nonforest estate land-use changes and management, ${ }^{9}$ especially concerning plantation developments. Nevertheless, in practical terms, the provincial and district Offices of Regional Land (Kantor Pertanahan Daerah) and the local chapters of the BPN (which are local representatives of the national level) still play a crucial role

\footnotetext{
7 In general, since decentralization came into effect, local governments have received a dramatic increase in revenues, especially from the balancing fund transferred by the national government (i.e. DBH (Dana Bagi Hasil Pajak/ Shared Revenues from Taxes), DAU (Dana Alokasi Umum / General Allocation Fund), and DAK (Dana Alokasi Khusus / Specific Allocation Fund). Although their revenues have increased, deforestation at the local level continues. A study that assesses the impacts of various fiscal variables on deforestation among different forested nations in developing countries concludes that, in the short run, an increase in a government's budget has positive association with forest land clearing (Galinato and Galinato 2013). 8 To date, of the balancing funds, only DAK has two environmentalrelated or earmarked funds, which are environmental DAK and forestry DAK (Resosudarmo and Abdurohman 2013).

9 See Articles 13 and 14 of Law No. 32 of 2004, and Government Regulation No. 38 of 2007.
} 
in providing services with regard to land certification issuance and monitoring; therefore, they have the power to influence land-use change by making processes more or less difficult for actors proposing such changes. Together, this means that while some authority in both forest and non-forest land is decentralized, central government actors continue to have strong influence in land-use decision making even when land is not directly under their control.

Approvals for many forms of land-use change, especially plantations in our cases, came directly from the head of district. Subdistricts and village governments only 'recommend' the land-use change, and all those in our study felt they lacked the power to disagree with the district head on land-use decisions even if they had authority to do so.

For REDD+, the distribution of authority is complicated further by the separation of the REDD+ Agency from the Ministry of Forestry, which controls most of the land with forest-carbon sources. Also, allocation and oversight of revenue streams from all economic activities remain the responsibility of the Ministry of Finance and are therefore disconnected from land-use decision making. Irawan et al. (2013) note that most revenue streams are channelled by the central government and distributed to provinces and districts through revenue-sharing mechanisms. If REDD+ were to follow the same centralized model, revenues would flow downward through nested levels of government, with each jurisdiction receiving an allocation. ${ }^{10}$ In contrast, plantations present an opportunity for district governments to obtain direct revenues through fees from land-use change (Irawan et al. 2013). Subnational actors stated that land-use decisions are often a trade-off between economic growth and carbon emissions reductions targets set by the central government.

In our research, we could see that the involvement of central government in REDD+ demonstration projects was stronger in Central Kalimantan than West Kalimantan. This was due to the identification of Central Kalimantan as a national demonstration site, where activities are focused in a heavily degraded area of peatland. This increased presence was accompanied by greater resentment of the central government

10 Note that Ministry of Forestry Regulation P.36/Menhut-II/2009, currently under review by the Ministry of Finance, does not specify how different levels of government will share such benefits. by subnational actors in Central Kalimantan, and their strong sense that 'local' solutions and expertise were being overlooked.

Overall, national- and district-level governments have the most authority over land-use change. However, when different levels of government disagreed with one another, district governments hesitated to contradict the national or provincial governments. Further, there is lack of clarity within various levels of government over which levels and sectoral offices have what jurisdiction, especially among institutions dealing with forests, the environment and plantations." Lastly, although Indonesia has decentralized significantly since 1998 with a major re-distribution of powers and responsibilities in 2004, decision making in forests remains highly centralized.

\section{Private companies}

Private companies have substantial formal and informal influence on land-use decision making in both forest and non-forest land. The companies identify the land they wish to hold under concession, negotiate the location permit, take the lead in meeting government requirements, engage with communities to produce the environmental impact assessment (AMDAL), and negotiate land-access rights with government and community landholders. The diligence taken with these processes depends on the attitudes of corporate managers and employees and their district government counterparts, leaving implementation of national law subject to local interpretations. As reported by communities, the AMDAL process was transparent in some cases, and in others, very opaque, such that it is not clear whether an approved AMDAL even exists. In our cases, although the Office of the Environment verifies the final document, corporations had significant leeway in terms of how the process was undertaken, which influenced the final results. We found the flexibility in rigor of implementation could lead to very positive or very negative environmental and social outcomes, depending on priorities of the company and district governments.

11 As of October 26, 2014, President Widodo merged the Ministries of Environment and Forestry, but this does not have an immediate impact on subnational departments. Several advocacy groups opposed the merger, noting that the Ministry of Environment served as a monitor to the Ministry of Forestry for some activities and now the merged ministry will be unchecked (Jong 2014). 


\section{Box 1. Local interpretations of information about land-use change: A comparison of oil palm cases in West and Central Kalimantan}

Our research included four cases of oil palm plantations: two in Central Kalimantan and two in West Kalimantan. All companies were obligated to apply the AMDAL, in accordance with national law. This includes not only an environmental assessment, but also consultation on the proposed land-use change and consent of the community. ${ }^{12}$ In three cases, the mechanisms were unclear: in one case, the village head may have consented; in two cases, consent may not have been granted at all. In all three cases, information provided regarding the conversion of land to oil palm included a list of promises to the community. These included roads, electrical supply, water supply, school construction and jobs; none had materialized at the time of writing, one to two years after oil palm activities had started. In addition, compensation for land conversion and profit sharing was promised according to Indonesian law.

In these three cases, community members were unhappy with any deal struck between the village head and the oil palm companies. Discontent manifested itself in several forms, ranging from open protest to conflict among community members. Many community members reported being coerced into making agreements with companies to grant access to land over which they had customary rights, or noted that customary land was allocated to companies without the consent of the customary user. In these cases, interviews suggest the village heads made backdoor arrangements with the companies to transfer permission to use the land. Since subsequent government actors relied on recommendations from lower levels, they approved the legal leases.

In the fourth case, which we view as an exception, the oil palm company consulted extensively with communities prior to commencing any activities on the ground and ensured broad-based consultation before obtaining the consent of communities in the AMDAL. In this case, communities and governments discussed in depth the costs and benefits of entering into an agreement with the company. While they may not have been aware of all the alternative uses of the land, they were thoroughly informed, and our research results suggest they provided free, prior and informed consent.

All four cases operated under the same national AMDAL, but implementation was completely different. In the fourth case, the process resulted in a strong relationship between the communities, government and company. It yielded benefits for communities in terms of compensation, profitsharing, infrastructure and training, as well and large tracts of forest conserved by the company within its concession.

12 According to paragraph (2) of article 26 of Law No. 32 of 2009 on Environmental Protection and Management, community participation needs to be based on the principle of good access to information, in which a proponent of a development project must provide 'transparent and complete information' to affected communities prior to developing their project.

\section{Bilateral and multilateral initiatives}

REDD+ is strongly influenced on various levels by several international actors: at the national level, the Indonesia-Australia Forest Carbon Partnership (IAFCP) in partnership with the Indonesian government; directly at the provincial levels through groups such as the Governors' Climate and Forest Task Force; in shaping REDD+ at international levels, such as the UN REDD+ Programme, including the FAO, UNDP and UNEP; as donors; or as buyers and certifiers of carbon credits.

There are similarities in some other sectors, such as the Roundtable on Sustainable Palm Oil (RSPO). International actors influence land use by setting the terms through which certain markets can be accessed, often involving mandatory social and environmental targets, like RSPO certified palm oil or certified carbon credits. Donors influence the terms and conditions of projects and therefore their implementation. Our study found that, in some instances, the terms of engagement that international actors impose can be viewed as compromising local priorities and processes, as we saw in a large REDD+ demonstration site. In that case, despite consultations, communities felt the donor's project parameters were too narrow to accommodate their suggestions adequately. In our research, we found that local communities criticized international actors that worked with national-level government more than those that worked with nongovernmental organizations (NGOs).

\section{NGOs in land-use changes}

$\mathrm{NGOs}$ come in many varieties. Some are aligned with local governments and viewed by communities as extensions of that government, as in a case we studied in a national park. In one conservation case, an NGO instigated a land-use change that excluded local people from customary forests. In other instances, NGOs play a community advocacy role, in which case they were sometimes viewed as 'agitators' by district levels of government and above. NGOs correspondingly have varying influence on land-use changes; they have more influence when their interests are aligned with decision-making levels of government, particularly the district and national levels. In practice, we found that NGOs aligned with communities had less influence on land-use change than those aligning with the government. 


\section{Customary users and local communities}

Our cases showed that customary users and local communities had the least amount of influence over large-scale land-use decisions. Despite processes aimed to safeguard customary user interests, like the AMDAL, these actors appear to have limited input. In one case, where a subdistrict government official described communities as having the "ultimate power", the community members described themselves as powerless against the government. More fundamentally, local communities and customary user land claims are not yet factored into spatial landuse planning (DTE 2012); this is expected to change with the Constitutional Court rulings. That is, the AMDAL, at least by law, recognizes the importance of customary users in land-use decisions; in practice, however, customary land claims are not actually registered in any central government repository, but are at best documented by NGOs. Opportunities for customary user participation beyond the initial 'consent' process are much weaker still, since formal complaint processes were not well defined in any of the cases we researched.

'Consent' is not a reliable indicator of popular agreement to a land-use change. In our study, one case involving the gazettement of a national park, as well as several REDD+ demonstrations and oil palm plantations, featured reports of misinformed consent from community leaders who made overly ambitious or false promises or omitted important facts around implications of land-use changes. In our interviews, community and government officials reported on false promises from companies, especially pertaining to material benefits such as infrastructure and facility provision. These promises were, on the whole, undocumented and expressed in terms that led community leaders to believe their implementation would be imminent. After operations began, companies we interviewed stated these provisions would come in time, but could not give a timeline. In the national park case, community leaders claim they were told only that the park would protect the forest against logging, not that it would exclude community members from customary lands.

In other words, although processes exist to include customary users and communities in land-use decision making, they are not always implemented in a way that includes these users; once the decision process is completed, these groups have few avenues for recourse or reconsideration (see also Colchester et al. 2006). Combined, these factors often lead to conflict, as we saw in the oil palm and national park cases. Moreover, they can also create a sense of resignation best captured by a community leader who stated that government and companies "don't really care about us". For more discussion on the implications of these issues on participation in society, sense of belonging as a citizen and recognition as a people, see Myers and Muhajir (forthcoming).

Our research results also suggest that even when customary users were consulted, the interest in, and ability to, negotiate land-use changes depended on several factors, including:

- The level of the community's practical control over the land compared to other users, especially levels of government (in some governance arrangements, even though under national law, local governments and customary users have come to an agreement on the management of land and resources).

- The level of solidarity within the community and whether they make decisions collectively or simply through leaders.

- The extent to which communities have engaged with commercial markets. More engagement may lead to increased tendency to trade land for compensation.

- Access to transportation and markets. If transportation is already sufficient, landuse changes offering increased access to transportation and markets may not have as much leverage.

- Livelihood alternatives available to communities. Those with few other alternatives may be more likely to negotiate high-risk land-use changes or ones that diminish community authority (especially forest conversion).

In summary, the implementation of consultation is too vaguely defined to secure community rights. Opportunities for communities to consent freely on land-use decisions are sometimes minimal. Even if they are consulted, other livelihood needs limit their negotiation power. Communities with less control over land, less community solidarity, less access to roads and fewer livelihood alternatives can be in a weaker bargaining position. 
Finally, in our research sites, consultation often took place with an elected representative of the government (head of village), who may or may not have also consulted with the broader community or with customary leaders. This proved problematic in several cases where communities were not informed of land-use decisions or provided an opportunity to contest or consent. Though the signature of the head of village complies with the letter of law, these decisions were widely contested.

We suggest that truly informed consent of landuse change includes consultation with a broad range of actors within communities rather than an overdependence on a small number of leaders who may not represent community interests. This level of consultation is possible through better alignment with free, prior and informed consent, including several open meetings with communities that explain not only potential benefits, but also costs, including opportunity costs. We also found several instances of extensive and broad community consultation, which led to less conflict and a higher sense of satisfaction with land-use changes. With the commitment by nine ministries and the REDD+ Agency on 1 September 2014 (Satriastanti 2014), recent signals suggest the participation of indigenous people in REDD+ will strengthen. How this will be operationalized remains, however, unclear.

\section{Conclusions for REDD+}

In our research, we found that one of the central concerns of subnational levels of government is how decentralized governments will be involved in REDD+, which will mostly be active in forests controlled by the Ministry of Forestry. This concern is largely based on subnational government perspectives that the REDD+ Agency and Ministry of Forestry are acting independently of each other and that national-level actors are seeking to make land-use decisions that directly affect subnational actors. Many actors regard incentives and regulatory arrangements for change as mismatched. Affected by the interests of these national actors, subnational actors are concerned their priorities may not be recognized and that their incentives for land-use change may be at odds with national level actors. Interviewees commonly mentioned the tension between reducing carbon emissions and increasing economic growth in regions that are economically dependent on natural resources.
Also, while they understand that decentralization is a work in progress (as one subnational government official said, "we are still learning" about how to function in a decentralized government), districts and provinces continue to harbor resentment toward national solutions for what they perceive as local issues. We suggest that REDD+ governance structures should build on existing decentralized government structures, which will require more regional and local involvement in forestland decision making than currently exists. International initiatives like the UN REDD+ Programme are partnering with nationally-led processes, while a funding mechanism like Financing REDD+ Indonesia (FREDDI) is developing at the central government level. Consequently, REDD+ proponents in Indonesia should engage in a process that clarifies and constructs a nested governance structure for REDD+ (see Sikor et al. 2010). This idea is challenged both by the lack of decentralization of Indonesia's forest estate and by the lack of decision-making power of key REDD+ actors, such as the REDD+ Agency and departments of environment at national and subnational levels, in land-use change. It is further complicated by the dual responsibility of the Ministry of Forestry to both exploit and protect forest resources.

Similar to other nationally legislated safeguards, such as AMDAL legislation and that pertaining to consultation with local communities prior to designation of forestlands (MK34/PUU-IX/2011), REDD+ proponents should continue to develop safeguards specific to carbon trading such as Ministry of Forestry Regulation P.36/Menhut-II/2009. That regulation details the benefit-sharing arrangements among government, community actors and developers, but is currently under review by the Ministry of Forestry. Importantly, as shown in this brief and detailed further in our reports, the implementation of these safeguards could be vulnerable to the same levels of variation in local interpretation as the AMDAL or forest gazettement. Therefore, the implementation of REDD+ should be consistent with national safeguarding laws by improved monitoring and verification through independent bodies within government or by third parties. Further, while national laws should leave room for local solutions, basic safeguarding laws should be defined so that fundamental concepts such as consultation and participation are more consistently implemented. This may include setting a minimum standard of consultation with a broader range of actors, enabling communities to participate in agreements on benefits, timelines and costs, including opportunity costs. 


\section{References}

Colchester M, Jiwan N, Andiko, Sirait M, Firdaus AY, Surambo A and Pane H. 2006. Promised land: Palm oil and land acquisition in Indonesia. Implications for local communities and indigenous peoples. Bogor, Indonesia: Forest Peoples Programme, Perkumpulan Sawit Watch, HuMA and the World Agroforestry Centre.

[DTE] Down to Earth. 2012. Indonesia's 'One map policy'. Accessed 3 June 2014. http://www.downtoearthindonesia.org/story/indonesia-s-one-map-policy Galinato G and Galinato S. 2013. The Role of Government Spending on Deforestation and Carbon Dioxide Emissions from Land-Use Change. Seattle: School of Economic Sciences, Washington State University.

Irawan S, Tacconi L and Ring I. 2013. Stakeholders' incentives for land-use change and REDD+: The case of Indonesia. Ecological Economics 87:75-83. doi: 10.1016/j. ecolecon.2012.12.018

Jong H. 2014. Jokowi's merging of environment, forestry ministries scorned. The Jakarta Post, 24 October. Accessed 24 October 2014. http://www.thejakartapost.com/ news/2014/10/24/jokowi-s-merging-environment-forestryministries-scorned.html

Resosudarmo BP and Abdurohman. 2013. Green fiscal policy strategies in response to climate change in Indonesia. In Mori A, Ekins P, Lee S, Speck S and Ueta K, eds. The Green Fiscal Mechanism and Reform for Low Carbon Development: East Asia and Europe. London: Routledge. 240-257.
Satriastanti FE. 1 September 2014. Nine Indonesian ministries declared support for indigenous people through REDD+. Ekuatorial. Accessed 2 September 2014. http://ekuatorial.com/en/forests/nineindonesian-ministries-declared-support-for-indigenouspeople-through-redd?utm_source=rss\&utm_ medium=rss\&utm_campaign=nine-indonesianministries-declared-support-for-indigenouspeople-through-redd - !/map $=4847 \&$ story $=$ post8580\&loc $=-6.653695352486294,106.248779296875,7$

Sikor T, Stahl J, Enters T, Ribot J, Singh N, Sunderlin WD and Wollenberg L. 2010. REDD-plus, forest people's rights and nested climate governance. Global Environmental Change 20(3):423-425. doi: 10.1016/j. gloenvcha.2010.04.007

This brief is based on two CIFOR research papers, which are forthcoming for download on the CIFOR website:

Myers R, Sanders A, Moeliano M and Rut D. Analyzing multilevel governance in Indonesia: Lessons for REDD+ through land-use change and benefit sharing in Central and West Kalimantan, Indonesia. Bogor, Indonesia: Center for International Forestry Research.

Ardiansyah F, Marthen AA and Amalia N. Forest and landuse governance in a decentralized Indonesia: A legal and policy review. Bogor, Indonesia: Center for International Forestry Research. 
This research was carried out by CIFOR as part of the CGIAR Research Program on Forests, Trees and Agroforestry (CRP-FTA). This collaborative program aims to enhance the management and use of forests, agroforestry and tree genetic resources across the landscape from forests to farms. CIFOR leads CRP-FTA in partnership with Bioversity International, CATIE, CIRAD, the International Center for Tropical Agriculture and the World Agroforestry Centre.

cifor.org

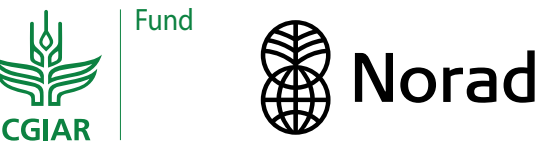

CGIAR
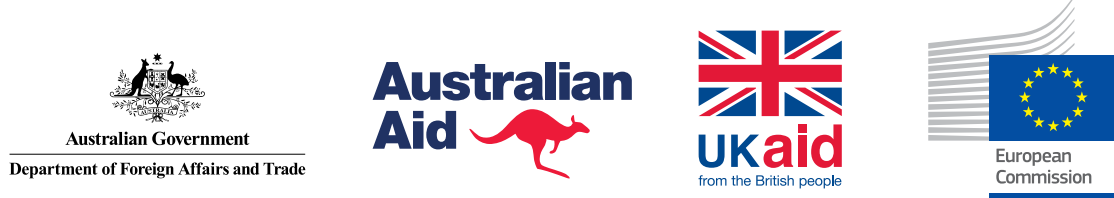

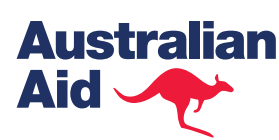 \\ Aid}

UKaid 